\title{
Environmental integrity and damselfly species composition in Amazonian streams at the "arc of deforestation" region, Mato Grosso, Brazil
}

Integridade ambiental e composição de espécies de Zygoptera em igarapés da Amazônia na região do "arco do desmatamento", Mato Grosso, Brasil

\author{
Leandro Schlemmer Brasil ${ }^{1,2}$, Joana Darc Batista ${ }^{1,2}$, Nubia França da Silva Giehl ${ }^{1,2}$, \\ Marco Bruno Xavier Valadão ${ }^{1,3}$, Josias Oliveira dos Santos ${ }^{1,3}$ and Karina Dias-Silva ${ }^{2,4}$ \\ ${ }^{1}$ Programa de Pós Graduação em Ecologia e Conservação, Universidade do Estado de Mato \\ Grosso - UNEMAT, CEP 78690-000, Nova Xavantina, MT, Brazil \\ e-mail: brasil_biologia@hotmail.com; joanadarcb@yahoo.com.br; nubiagiehl@gmail.com; \\ marcobrunovaladáo@gmail.com; jhoesan@gmail.com \\ ${ }^{2}$ Laboratório de Entomologia Aquática, Universidade do Estado de Mato Grosso - UNEMAT, \\ CEP 78690-000, Nova Xavantina, MT, Brazil \\ e-mail: karinabionx@gmail.com \\ ${ }^{3}$ Laboratório de Ecologia Vegetal, Universidade do Estado de Mato Grosso - UNEMAT, \\ CEP 78690-000, Nova Xavantina, MT, Brazil \\ ${ }^{4}$ Programa de Pós-Graduação em Ciências Ambientais, Universidade Federal de Goiás - UFG, \\ CEP 74001-970, Goiânia, GO, Brazil
}

\begin{abstract}
Aims: Investigated how the loss of environmental integrity affects damselfly species composition in nine sites with different levels of environmental integrity in a Cerrado-Amazon transition region known as "arc of deforestation" in Mato Grosso State, Brazil. We also tested the influence of environmental variables on species composition. Methods: We collected in transects of $100 \mathrm{~m}$ and used ordination (PCoA) and simple linear regression. Results: Species composition was strongly influenced by the environmental quality of sites, and the best model to explain species composition included variables related to channel morphology. Conclusions: These results are connected to the environmental homogenization and loss of environmental integrity as a result of extensive agricultural practices which alter stream communities of dragonflies in this region.
\end{abstract}

Keywords: environmental change, water resources, biological indicator, Amazon.

Resumo: Objetivos: Investigamos como a perda da integridade ambiental afeta a composição de espécies de Zygoptera em nove locais com diferentes níveis de integridade ambiental da região de transição Cerrado-Amazônia conhecido como "arco do desmatamento" no Estado de Mato Grosso, Brasil. Nós também testamos a influência das variáveis ambientais sobre a composição de espécies. Métodos: Foram coletadas em transecçôes de $100 \mathrm{~m}$ e usado ordenação (PCoA) e regressão linear simples. Resultados: A composição de espécies foi fortemente influenciada pela qualidade ambiental do sítio, e o melhor modelo para explicar a composição de espécies inclui variáveis relacionadas à morfologia do canal. Conclusóes: Estes resultados estáo ligados à homogeneizaçáo ambiental e perda da integridade ambiental como resultado de amplas práticas agrícolas que alteram as comunidades de libélulas de riachos nesta região.

Palavras-chave: alteração ambiental, recursos hídricos, bioindicador, Amazônia.

\section{Introduction}

Large-scale agriculture is the main cause of deforestation in the Amazônia (Macedo et al., 2013; Neill et al., 2013). One of the most deforested regions in Brazil is the agricultural frontier in Southern Amazon. This region is known as the "Arc of Deforestation" (Nogueira et al., 2007, 2008) due to extensive changes in natural landscapes due to agricultural expansion.

This environmental homogenization decreases biodiversity (Fischer and Lindenmayer, 2007). Alterations usually begin with changes in land use and removal of riparian vegetation, resulting 
in the channel structure of water courses (Allan, 2004; Bacellar, 2005). All these changes increase sedimentation and change the hydrological cycle, decreasing water quality (Callisto et al., 2001).

The removal of riparian vegetation in tropical environments has a negative effect on aquatic macroinvertebrates, due to increased sunlight incidence, eutrophication, decrease of both substrate and resource availability (Bojsen and Jacobsen, 2003; Bispo et al., 2006). Thus, understanding how aquatic insect communities respond to environmental changes becomes a fundamental tool for monitoring water quality and assessing the integrity of aquatic ecosystems (Bonada et al., 2006; Lammert and Allan, 1999).

Dragonflies are well-known indicators of changes in aquatic ecosystems, often used to detect loss of environmental integrity (Watson et al., 1982; Carvalho et al., 2013; Monteiro-Júnior et al., 2013). Habitat heterogeneity is a good predictor of the abundance and richness of dragonflies (Chovanec, 1994), so that environmental homogenization might have deep impacts on community structure (Ligeiro et al., 2013).

The headwaters of the Rio Xingu river are located in eastern Mato Grosso State in central Brazil. However, wild areas of this region have been continuously used to agricultural activities (Brannstrom et al., 2008). Such environmental changes may have strong impacts on the water quality of this large river (Sanchez et al., 2012). Several studies have evaluated the consequences of these alterations in aquatic systems (e.g., Dias-Silva et al., 2010; Shimano et al., 2010; Silva et al., 2010; Souza et al., 2011; Pereira et al., 2012; Brasil et al., 2013; Carvalho et al., 2013). However, further studies are needed to understand and track the effects of environmental changes on biodiversity.

Given the intense conversion of native vegetation into agricultural landscapes, and the need to understand the consequences of these disturbances on insects, we analyzed how the loss of environmental integrity affects adult dragonfly species composition and which environmental variables most influence community structure. We tested the hypothesis that the loss of environmental integrity will change the relative abundance of specialists and generalists in adult dragonfly communities, due to partial or total species turnover driven by environmental alteration.

\section{Material and Methods}

\subsection{Studied area}

We sampled nine sites in tributary streams of the Rio Tanguro, in the Rio Xingu Basin, Querência municipality, Mato Grosso State, southern Brazilian Amazonia, in September 2012 (Figure 1). This region is an agricultural frontier known as the "arc of deforestation” (Corrêa, 2002), mixing Cerrado and Amazonia Domains. All streams sampled are surrounded by a matrix of soybean crops. The climate is classified as Aw in the Köppen system (Peel et al., 2007), seasonal tropical with two distinct seasons: a dry season from May to October and a rainy season from November to April. The annual rainfall in 2012 was $1,564 \mathrm{~mm}$ and the mean monthly temperature was $25.2{ }^{\circ} \mathrm{C}$ (Information Environmental Research Institute of Amazonia - IPAM).

\subsection{Sampling design}

We sampled adult damselflies in three headwater streams using a 60 centimeter-diameter entomological aerial net. We established three transects (100-m linear) on the right margin of each stream, totaling nine transects (Figure 1). Each transect was divided into 20 segments of $5 \mathrm{~m}$, with a sampling effort of $1.66 \mathrm{~meter} / \mathrm{min}$ on average (Marco Junior, 1998; Ferreira-Peruquetti and Marco Junior, 2002). Samplings were conducted during peak of activity of dragonflies between $11 \mathrm{~h} 30$ and 14h00 (Corbet, 1999).

Specimens were identified comparing with the figures presented in Lencioni $(2005,2006)$ and Garrison et al. (2010), and additional consult to specialists. When identification to the species level was not possible, specimens were assigned only to generic level. All specimens are housed at the "Coleção Zoobotânica James Alexander Ratter", of the University of the State of Mato Grosso, Nova Xavantina municipality, Mato Grosso State, Brazil (CZNX).

\subsection{Habitat integrity}

We used the Habitat Integrity Index (HII; Nessimian et al., 2008) to quantify conservation status of the sampled streams. This index combines the measurement of 12 environmental characteristics, namely: (1) land use pattern adjacent to the riparian vegetation, (2) the width and (3) integrity of riparian vegetation, (4) the state of riparian vegetation in a range of $10 \mathrm{~m}$, (5) presence of retention devices, (6) channel 


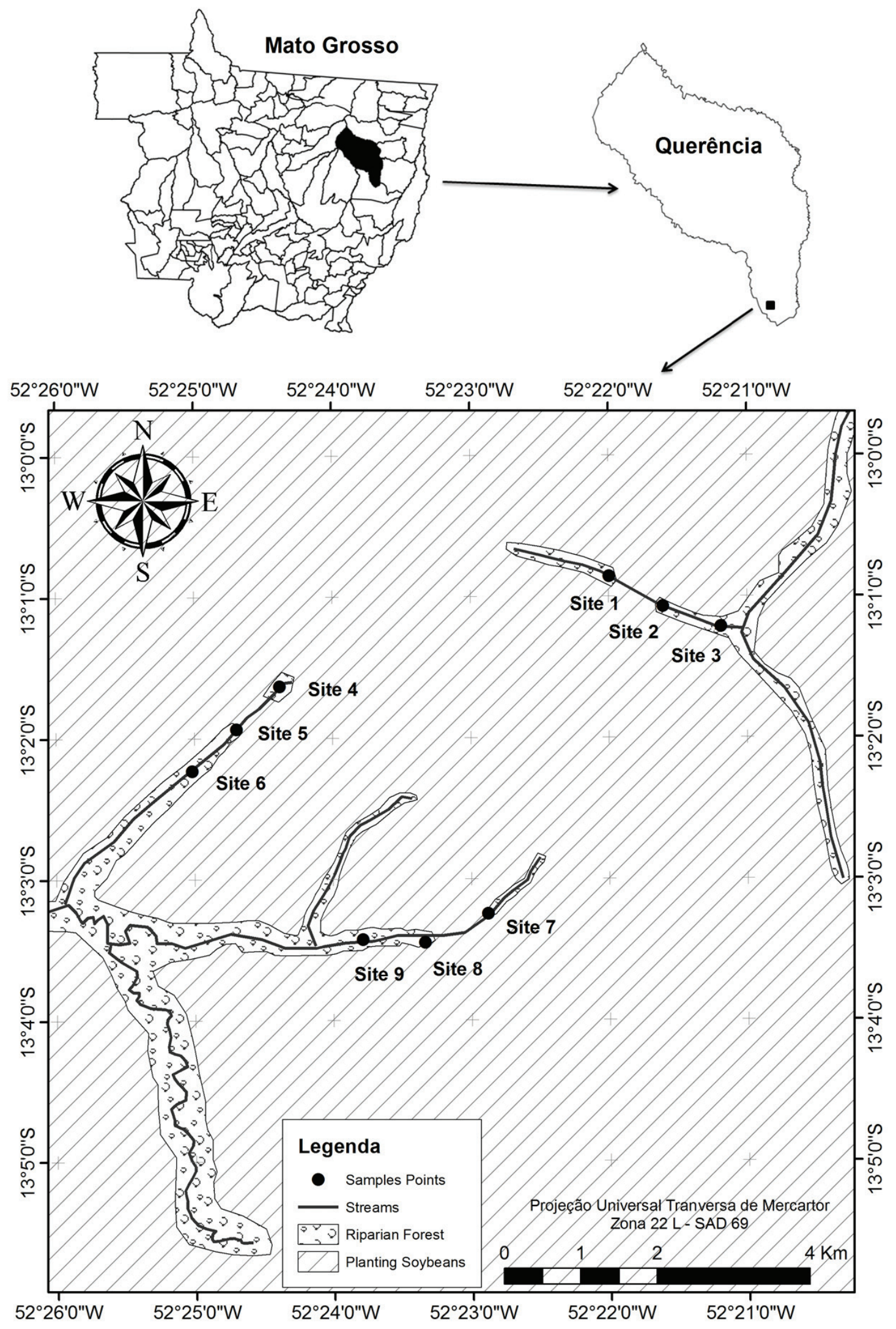

Figure 1. Location of studied streams in southern Amazonia, Querência municipality, Mato Grosso State, Brazil. 
sediment, (7) bank structure (8), and undercutting, (9) status of the stream bed, (10) riffles, pools, or meanders, (11) presence of aquatic vegetation in stream bed (12) presence of detritus in the channel. Furthermore, (13) riparian vegetation continuous or fragmented, which is a peculiar characteristic of our sampling sites was also included in our analysis.

Each item was composed of four to six alternatives ordered in relation to perceived aspects of habitat integrity. The final index is the mean value for the total sampled habitat characteristics. These transformations produce an index that vary between 0 and 1 and that is directly related to the integrity of habitat conditions, the more intact a site the closer to 1 the HII (Nessimian et al., 2008). This index has been shown to be a good predictor of aquatic insect species composition in tropical streams under high anthropogenic pressure (e.g., Dias-Silva et al., 2010; Silva et al., 2010; Souza et al., 2010, 2011; Juen and Marco Junior, 2011; Pereira et al., 2012; Pinto et al., 2012; Carvalho et al., 2013; Brasil et al., 2013; Monteiro-Júnior et al., 2014).

\subsection{Data analysis}

A Principal Coordinates Analysis (PCoA) was used to analyze the similarity in species composition throughout transects, based on BrayCurtis dissimilarity index (Clarke, 1993). Data on species abundance were previously log transformed (Legendre and Legendre, 2012). A randomization procedure (999) was used to test the significance of each eigenvector (axis) to be retained for further analyses of ordenation (PCoA). Then, a simple linear regression (Zar, 2010) was used to test the relationship between HII of each transect and the PCoA 1.

Additionally, the BioEnv approach was used to find which environmental characteristics were more correlated with species composition (Melo 2009). This method finds the subset of variables that have the highest correlation with the species dissimilarity matrix (Clarke and Ainsworth, 1993). This analysis was run using the $\mathrm{R}$ package vegan ( $\mathrm{R}$ Development Core Team 2012).

\section{Results}

We collected 104 specimens from 17 species. The most abundant species were Epipleoneura williamsoni Santos, 1957 ( $\mathrm{n}=41 ; 39.42 \%$ of total), followed by Epipleoneura metallica Rácenis, 1955 $(\mathrm{n}=20 ; 19.23 \%)$ (Table 1). Epipleoneura williamsoni was the most abundant species in the most preserved transect $(\mathrm{HII}=0.76)$ The PCoA 1 explained $45 \%$ of
Table 1. Abundances of damselflies species in the nine transects of three streams in southern Amazon, Querência municipality, Mato Grosso State, Brazil.

\begin{tabular}{lc}
\hline \multicolumn{1}{c}{ Family/Species } & Abundance \\
\hline Coenagrionidae & 3 \\
Acanthagrion apicale Selys, 1876 & 2 \\
Acanthagrion gracile (Rambur, 1846) & 2 \\
Acanthagrion sp. & 3 \\
Argia lilacina Selys, 1865 & 2 \\
Argia reclusa Selys, 1865 & 1 \\
Argia tinctipennis Selys, 1865 & 3 \\
Argia sp. & 1 \\
Telebasis coccinea (Selys, 1876) & 1 \\
Telebasis gigantea Daigle, 2002 & 1 \\
Telebasis racenisi Bick \& Bick, 1995 & 1 \\
Telebasis sp. & 1 \\
Tuberculobasis inversa (Selys, 1876) & \\
Calopterygidae & 17 \\
Hetaerina curvicauda Garrison, 1990 & 2 \\
Hetaerina sp. & \\
Protoneuridae & 20 \\
Epipleoneura metallica Rácenis, 1955 & 31 \\
Epipleoneura williamsoni Santos, 1957 & 41 \\
Phasmoneura janirae Lencioni, 1999 & \\
Total & \\
\hline & \\
\hline
\end{tabular}

the variation in species composition and separated the preserved transects in right and the most altered ones in the left (Figure 2).

The HII showed a positive relationship with PCoA $1\left(\mathrm{R}^{2}=0.495, p<0.034\right.$; Figure 3$)$. Furthermore, the subset of environmental variables best correlated $(r=0.52)$ with community similarity included: width of riparian vegetation, bank undercutting and presence of detritus in the channel, however, individually bank undercutting was the variable that best relates with the fauna (Table 2).

\section{Discussion}

Habitat integrity had a positive effect on species composition, demonstrating the importance of conserving these habitats for maintaining damselflies species composition in small streams that are under anthropogenic pressure. Besides capturing overall habitat quality, the HII also is useful to understand the influence of environmental on biodiversity, since environmentally degraded sites are less diverse due to the removal of riparian vegetation or channel homogenization through siltation, deposition of debris, or stream bank excavations (Nessimian et al., 2008). Thus, it seems that environmental homogenization is the main driver of changes in species composition. 


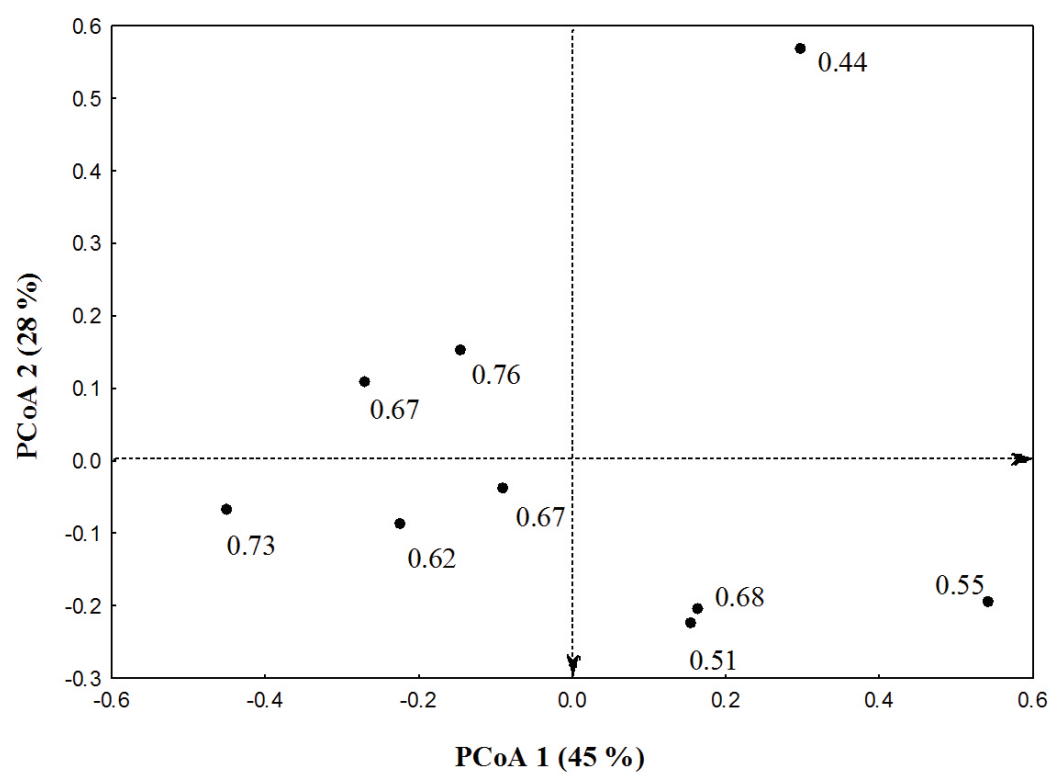

Figure 2. Ordination plot of community similarity of damselflies in nine streams in southern Amazon, Querência municipality, Mato Grosso State, Brazil. The numbers refer to the Habitat Integrity Index (HII, Nessimian et al., 2008) of each transect.

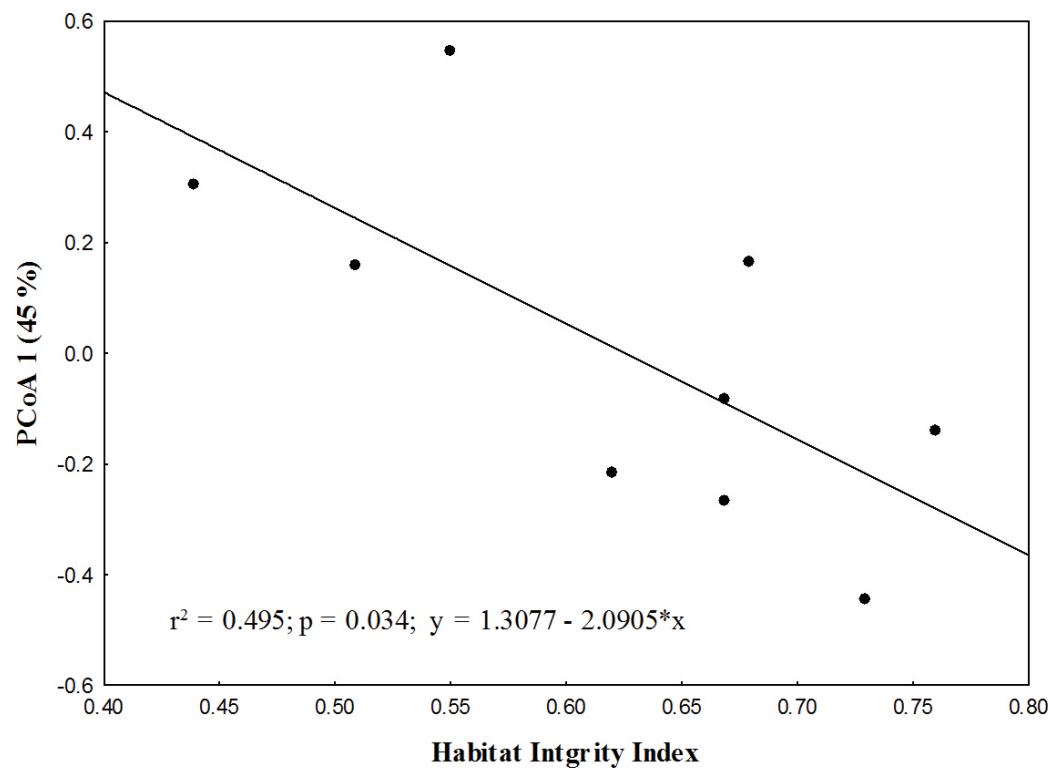

Figure 3. Relationship between the Habitat Integrity Index and the PCoA 1 for nine streams in southern Amazon, Querência municipality, Mato Grosso State, Brazil.

Environmental heterogeneity strongly influences the distribution of aquatic organisms (Popielarz and Neal, 2007), since it promotes species coexistence through niche partitioning (Holzman et al., 2011; Heino and Grönroos, 2013). Thus, environmental homogenization can cause a decline in diversity and the replacement of specialist by generalist species (Popielarz and Neal, 2007). Since habitat integrity may be a surrogate for the amount of energy available in the system, allowing the stable coexistence of species in one site (Wright, 1983).

Changes in damselflies community structure are usually related to the decrease in habitat integrity (e.g., Muller et al., 2003; Silva et al. 2010; Pinto et al. 2012; Carvalho et al. 2013; Monteiro-Junior et al., 2013). Our results show that the conservation and restoration of areas in a region known as the "arc of deforestation” southern Amazon (Corrêa, 2002; 


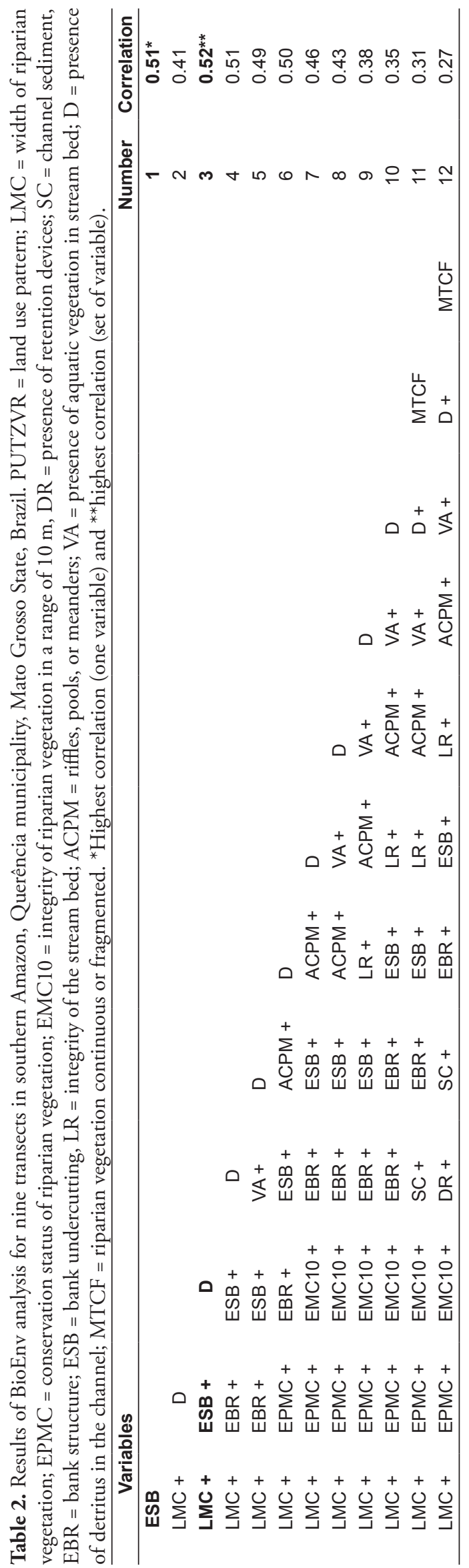


Fearnside, 2005) is crucial for the maintenance of species diversity of damselflies in the future.

The subset of variables best correlated with community dissimilarity is mainly related to channel morphology (bank undercutting and presence of detritus in the channel). These variables are key to damselflies, since they are predatory organisms and the majority of species are territorials (Corbet and May, 2008; Pinto et al., 2013). Thus, changes in these variables can reduce microhabitat complexity and habitat patch availability, influencing the competition for space to forage near water surface, since adults mainly use visual cues to evaluate habitat quality for breeding, and tactile cues for habitat selection for oviposition (Bernáth et al., 2002). In addition, changes in those variables are key not only for the establishment of damselflies larvae, but also their prey (e.g., Ephemeroptera, Plecoptera, and Thichoptera) that are widely known to be sensitive to environmental changes in streams (Pereira et al., 2012; Brasil et al., 2013; Ligeiro et al., 2013; Suga and Tanaka, 2013; Wahl et al., 2013). Thus, the decrease in their prey in the most altered sites may indirectly influence the community composition of dragonflies (Peckarsky, 1980; Crowley and Johnson, 1992). Accordingly, our results suggest that damselflies diversity is controlled by bottom-up forces (Begon et al., 2007), which is commonly reported for aquatic environments (McQueen et al., 1989; Wesner, 2010).

Besides the channel morphology, the width of the riparian zone was also highly correlated with species composition. The total or partial removal of the riparian zone changes the microclimate of streams by creating patches of unshaded areas that have a higher light incidence. The random distribution of these patches along streams may change species composition, since species preferentially inhabit patches with better conditions for their development (Thorp et al., 2006).

Previous studies have reported that changes in the riparian zone affect odonates. For example, there is a decrease in the richness of zygopterans but an increase of anisopterans, therefore changing species composition in altered environments (Carvalho et al., 2013; Monteiro-Júnior et al. 2013, 2014).

Since our sampling sites are surrounded by a matrix of soybean crops, our results provide key local scale information about the influence of environmental changes on damselflies community structure in a region densely altered by extensive agricultural activities in the Amazon. Therefore, our results may be useful to inform future management and environmental monitoring plans.

\section{Conclusions}

The decrease in environmental integrity significant influenced damselflies species composition. Variables related to stream channel structure and preservation riparian forest were the best correlates of community dissimilarity. Our results showed that the homogenization resulting from loss of environmental integrity negatively influences damselflies community structure in streams in an area under strong anthropogenic pressure.

\section{Acknowledgements}

We thank the PRPPG-EC / UNEMAT for support field. The autors L. S. Brasil, N. F. S. Giehl and J. O. Santos thanks CAPES, M. B. X. Valadão thanks FAPEMAT and K. Dias-Silva, J.D. Batista thanks the CNPQ, by the scholarship (DCR:\# 350790/2013-2). Diogo B. Provete helped with English language. The CAPES/PROCAD (\#109/2007) and PELD (\#558069/2009-6). Ulisses G. Neiss (UFAM) helped with taxonomic identification and Eduardo Queiroz Marques for preparing the map. IPAM provided logistics during field work. Several undergrad students from UNEMAT helped in fieldwork.

\section{References}

ALLAN, JD. 2004. Landscape and riverscapes: the influence of land use on stream ecosystems. Annual Review of Ecology, Evolution, and Systematics, vol. 35, p. 257-284. http://dx.doi.org/10.1146/annurev. ecolsys.35.120202.110122

BACELLAR, LAP. 2005. O papel das florestas no regime hidrológico de bacias hidrográficas. Geo.br, vol. 1, p. 1-39.

BEGON, M., TOWNSEND, CR. and HAPER, JL. 2007. Ecologia: de indivíduos a ecossistemas. 4. ed. Porto Alegre: Artmed. 720 p.

BERNÁTH, B., SZEDENICS, G., WILDERMUTH, H. and HORVÁTH, G. 2002. How can dragonflies discern bright and dark waters from a distance? The degree of polarization of reflected light as a possible cue for dragonfly habitat selection. Freshwater Biology, vol. 47, no. 9, p. 1707-1719. http://dx.doi. org/10.1046/j.1365-2427.2002.00931.x

BISPO, PC., OLIVEIRA, LG., BINI, LM. and SOUSA, KG. 2006. Ephemeroptera, Plecoptera and Trichoptera assemblages from riffles in mountain streams of Central Brazil: environmental factors influencing the distribution and abundance of 
immatures. Brazilian Journal of Biology, vol. 66, no. 2b, p. 611-622. PMid:16906293. http://dx.doi. org/10.1590/S1519-69842006000400005

BOJSEN, BH. and JACOBSEN, D. 2003. Effects of deforestation on macroinvertebrate diversity and assemblage structure in Ecuadorian Amazonian streams. Archiv für Hydrobiologie, vol. 158, no. 3, p. 317-342. http://dx.doi.org/10.1127/00039136/2003/0158-0317

BONADA, N., PRAT, N., RESH, VH. and STATZNER, B. 2006. Developments in aquatic insect biomonitoring: a comparative analysis of recent approaches. Annual Review of Entomology, vol. 51, p. 495-523. PMid:16332221. http://dx.doi. org/10.1146/annurev.ento.51.110104.151124

BRANNSTROM, C., JEPSON, W., FILIPPI, AM., REDO, D., XU, Z. and GANESH, S. 2008. Land change in the Brazilian Savanna (Cerrado), 19862002: comparative analysis and implications for landuse policy. Land Use Policy, vol. 25, no. 4, p. 579-595. http://dx.doi.org/10.1016/j.landusepol.2007.11.008

BRASIL, LS., SHIMANO, Y., BATISTA, JD. and CABETTE, HSR. 2013. Effects of environmental factors on community structure of Leptophlebiidae (Insecta: Ephemeroptera) in Cerrado streams, Brazil. Iheringia, Série Zoologia, vol. 103, no. 3, p. 260-265. http://dx.doi.org/10.1590/S007347212013000300008

CALLISTO, M., MORETTI, M. and GOULART, M. 2001. Macroinvertebrados bentônicos como ferramenta para avaliar a saúde de riachos. Revista Brasileira de Recursos Hidricos, vol. 6, no. 1, p. 71-82.

CARVALHO, FG., OLIVEIRA-JUNIOR, JMB., FARIA, APJ. and JUEN, L. 2013. Uso da curva abc como método para detectar o efeito de modificação antropogênica sobre assembleia de Odonata (insecta). Interciencia, vol. 38, no. 7, p. 516-522.

CHOVANEC, A. 1994. Libellen als Bioindikatoren. Anax, vol. 1, no. 1, p. 1-9.

CLARKE, KR. 1993. Non-parametric multivariate analyses of changes in community structure. Australian Journal of Ecology, vol. 18, no. 1, p. 117143. http://dx.doi.org/10.1111/j.1442-9993.1993. tb00438.x

CLARKE, KR. and AINSWORTH, M. 1993. A method of linking multivariate community structure to environmental variables. Marine Ecology-Progress Series, vol. 92, p. 205-205. http://dx.doi.org/10.3354/ meps092205

CORBET, PS. 1999. Dragonflies: behavior and ecology of Odonata. Ithaca: Comstock. 829 p.

CORBET, PS. and MAY, ML. 2008. Fliers and perchers among Odonata: dichotomy or multidimensional continuum? A provisional reappraisal. International Journal Of Odonatology, vol. 11, no. 2, p.155-171. http://dx.doi.org/10.1080/13887890.2008.9748320
CORRÊA, JC. 2002. Efeito de sistemas de cultivo na estabilidade de agregados de um Latossolo VermelhoAmarelo em Querência, MT. Pesquisa Agropecuária Brasileira, vol. 37, no. 2, p. 203-209.

CROWLEY, PH. and JOHNSON, DM. 1992. Variability and stability of a dragonfly assemblage. Oecologia, vol. 90, no. 2, p. 260-269.

DIAS-SILVA, K., CABETTE, HSR., JUEN, L. and MARCO JUNIOR, P. 2010. The influence of habitat integrity and physical-chemical water variables on the structure of aquatic and semi-aquatic Heteroptera. Zoologia, vol. 27, no. 6, p. 918-930. http://dx.doi. org/10.1590/S1984-46702010000600013

FEARNSIDE, PM. 2005. Deforestation in Brazilian Amazonia: history, rates, and consequences. Conservation Biology, vol. 19, no. 3, p. 680-688. http:// dx.doi.org/10.1111/j.1523-1739.2005.00697.x

FERREIRA-PERUQUETTI, PS. and MARCO JUNIOR, P. 2002. Efeito da alteraçáo ambiental sobre a comunidade de Odonata em riachos de Mata Atlântica de Minas Gerais, Brasil. Revista Brasileira de Zoologia, vol. 19, no. 2, p. 317-327. http://dx.doi. org/10.1590/S0101-81752002000200002

FISCHER, J. and LINDENMAYER, DB. 2007. Landscape modification and habitat fragmentation: a synthesis. Global Ecology and Biogeography, vol. 16, no. 3, p. 265-280. http://dx.doi.org/10.1111/j.14668238.2007.00287.x

GARRISON, RW., VON ELLENRIEDER, N. and LOUTON, JA. 2010. Damselfly genera of the new world: an illustrated and annotated key to the Zygoptera. Baltimore: Johns Hopkins University Press. $490 \mathrm{p}$.

HEINO, J. and GRÖNROOS, M. 2013. Does environmental heterogeneity affect species cooccurrence in ecological guilds across stream macroinvertebrate metacommunities? Ecography, vol. 36, no. 8, p. 926-936. http://dx.doi.org/10.1111/ j.1600-0587.2012.00057.x

HOLZMAN, R., COLLAR, DC., MEHTA, RS. and WAINWRIGHT, PC. 2011. Functional complexity can mitigate performance trade-offs. The American Naturalist, vol. 177, no. 3, p. 69-83. PMid:21460535. http://dx.doi.org/10.1086/658366

JUEN, L. and MARCO JUNIOR, P. 2011. Odonate biodiversity interra-firme forest streamlets in Central Amazonia: on the relative effects of neutral and niche drivers at smallgeographical extents. Insect Conservation Diversity, vol. 4, no. 4, p. 265-274. http://dx.doi.org/10.1111/j.17524598.2010.00130.x

LAMMERT, M. and ALLAN, JD. 1999. Assessing biotic integrity of streams: effects of scale in measuring the influence of land use/cover and habitat structure on fish and macroinvertebrate. Environmental Management, vol. 23, no. 2, p. 257- 
270. PMid:9852191. http://dx.doi.org/10.1007/ s002679900184

LEGENDRE, P. and LEGENDRE, L. 2012. Numerical ecology. Amsterdam: Elsevier. 899 p.

LENCIONI, FAA. 2005. Damselflies of Brazil: an illustrated guide. São Paulo: All Print. 332 p. (Noncoenagrionidae Families, v. 1).

LENCIONI, FAA. 2006. Damselflies of Brazil: an illustrated guide. São Paulo: All Print. 419 p. (Coenagrionidae, v. 2).

LIGEIRO, R., HUGHES, RM., KAUFMANNC, PR., MACEDO, DR., FIRMIANO, KR., FERREIRA, WR., OLIVEIRA, D., MELO, AS. and CALLISTO, M. 2013. Defining quantitative stream disturbance gradients and the additive role of habitat variation to explain macroinvertebrate taxa richness. Ecological Indicators, vol. 25, p. 45-57. http://dx.doi. org/10.1016/j.ecolind.2012.09.004

MACEDO, MN., COE, MT., DEFRIES, R., URIARTE, M., BRANDO, PM., NEILL, C. and WALKER, WS. 2013. Land-use-driven stream warming in southeastern Amazonia. Philosophical Transactions of the Royal Society B, vol. 368, no. 1619, p. 1-9.

MARCO JUNIOR, P. 1998. The Amazonian Campina dragonfly assemblage: patterns in microhabitat use and behavior in a foraging habitat. Odonatologica, vol. 27 , no. 2, p. 239-248.

MCQUEEN, DJ., JOHANNES, MRS. and POST, JR. 1989. Bottom-up and top-down impacts on freshwater pelagic community structure. Ecological Monographs, vol. 59, no. 3, p. 289-309. http://dx.doi. org/10.2307/1942603

MELO, AS. 2009. Explaining dissimilarities in macroinvertebrate assemblages among stream sites using environmental variables. Zoologia, vol. 26, no. 1, p. 79-84. http://dx.doi.org/10.1590/S198446702009000100013

MONTEIRO-JÚNIOR, CS., COUCEIRO, SRM., HAMADA, N. and JUEN, L. 2013. Effect of vegetation removal for road building on richness and composition of Odonata communities in Amazonia, Brazil. International Journal of Odonatology, vol. 16, no. 2, p. 135-144. http://dx.doi.org/10.1080/1388 7890.2013 .764798

MONTEIRO-JÚNIOR, CS., JUEN, L. and HAMADA, N. 2014. Effects of urbanization on stream habitats and associated adult dragonfly and damselfly communities in central Brazilian Amazonia. Landscape and Urban Planning, vol. 127, p. 28-40. http:// dx.doi.org/10.1016/j.landurbplan.2014.03.006

MÜLLER, Z., JAKAB, T., TÓTH, A., DÉVAI, G., SZÁLLASSY, N., KISS, B. and HORVÁTH, R. 2003. Effect of sports fisherman activities on dragonfly assemblages on a Hungarian river floodplain. Biodiversity \& Conservation, vol. 12, no. 1, p. 167179. http://dx.doi.org/10.1023/A:1021220220039
NEILL, C., COE, MT., RISKIN, SH., KRUSCHE, AV., ELSENBEER, H., MACEDO, MN., MCHORNEY, R., LEFEBVRE, P., DAVIDSON, EA., SCHEFFLER, R., FIGUEIRA, AMS., PORDER, S. and DEEGAN, LA. 2013. Watershed responses to Amazon soya bean cropland expansion and intensification. Philosophical Transactions of the Royal Society B, vol. 368, no. 1619, p. 1-7. PMid:23610178 PMCid:PMC3638438. http:// dx.doi.org/10.1098/rstb.2012.0425

NESSIMIAN, JL., VENTICINQUE, EM., ZUANON, J., MARCO JUNIOR, P., GORDO, M., FIDELIS, L., BATISTA, JD. and JUEN, L. 2008. Land use, habitat integrity, and aquatic insect assemblages in Central Amazonian streams. Hydrobiologia, vol. 614, no.1, p. 117-131. http://dx.doi.org/10.1007/s10750008-9441-x

NOGUEIRA, EM., FEARNSIDE, PM., NELSON, BW. and FRANÇA, MB. 2007. Wood density in forests of Brazil's 'arc of deforestation': implications for biomass and flux of carbon from land-use change in Amazonia. Forest Ecology and Management, vol. 248, no. 3, p. 119-135. http://dx.doi.org/10.1016/j. foreco.2007.04.047

NOGUEIRA, EM., NELSON, BW., FEARNSIDE, PM., FRANÇA, MB. and OLIVEIRA, ACA. 2008. Tree height in Brazil's 'arc of deforestation': shorter trees in south and southwest Amazonia imply lower biomass. Forest Ecology and Management, vol. 255, no. 7, p. 2963-2972. http://dx.doi.org/10.1016/j. foreco.2008.02.002

PECKARSKY, BL. 1980. Predator-prey interactions between stoneflies and mayflies: behavioral observations. Ecology, vol. 61, no. 4, p. 932-943. http://dx.doi.org/10.2307/1936762

PEEL, MC., FINLAYSON, BL. and MCMAHON, TA. 2007. Updated world map of the KöppenGeiger climate classification. Hydrology and Earth System Sciences, vol. 11, p. 1633-1644. http://dx.doi. org/10.5194/hess-11-1633-2007

PEREIRA, LR., CABETTE, HSR. and JUEN, L. 2012. Trichoptera as bioindicators of habitat integrity in the Pindaíba river basin, Mato Grosso (Central Brazil). Annales de Limnologie - International Journal of Limnology, vol. 48, no. 3, p. 295-302. http://dx.doi. org/10.1051/limn/2012018

PINTO, NS., JUEN, L., CABETTE, HSR. and MARCO JUNIOR, P. 2012. Fluctuating assymmetry and wing size of Argia tinctipennis Selys (Zygoptera: Coenagrionidae) in relation to riparian forest preservation status. Neotropical Entomology, v. 41, no. 3, p. 178-185. PMid:23950041. http://dx.doi. org/10.1007/s13744-012-0029-9

PINTO, NS., HIDASI, J., RIBEIRO, V., RODRIGUES, AM., BRANDÃO, BR. and ROCHA, CO. 2013. Efeito da presença de vizinhos sobre o comportamento territorial de Perithemis mooma (Kirby) (Anisoptera: 
Libellulidae). EntomoBrasilis, vol. 6, no. 2, p. 104107. http://dx.doi.org/10.12741/ebrasilis.v6i2.285

POPIELARZ, PA. and NEAL, ZP. 2007. The niche as a theoretical tool. Annual Review of Sociology, vol. 33, p. 65-84. http://dx.doi.org/10.1146/annurev. soc.32.061604.123118

R DEVELOPMENT CORE TEAM. 2012. R: A language and environment for statistical computing. Version 2.15.1. Vienna: R Foundation for Statistical Computing. Available from: <http://www.R-project. org>. Access in: 1 out. 2013.

SANCHEZ, RA., ROSSETE, AN., REZENDE, ACP., ALVES, HQ. and VILLAS-BÔAS, A. 2012. Subsídios para a proteçáo de áreas úmidas da bacia do rio Xingu (Mato Grosso, Brasil). Revista Árvore, vol. 36, no. 3, p. 489-498. http://dx.doi. org/10.1590/S0100-67622012000300011

SHIMANO, Y., CABETTE, HSR., SALLES, FF. and JUEN, L. 2010. Composição e distribuição da fauna de Ephemeroptera (Insecta) em área de transição Cerrado-Amazônia, Brasil. Iheringia, Série Zoologia, vol. 100, no. 4, p. 301-308. http://dx.doi. org/10.1590/S0073-47212010000400004

SILVA, DP., MARCO, P. and RESENDE, DC. 2010. Adult odonate abundance and community assemblage measures as indicators of stream ecological integrity: a case study. Ecological Indicators, vol. 10, no. 3, p. 744-752. http://dx.doi.org/10.1016/j. ecolind.2009.12.004

SOUZA, HML., JUEN, L. and CABETTE, HSR. 2010. Diversidade beta de Baetidae (Ephemeroptera) em córregos da Bacia Hidrográfica do Rio Pindaíba/MT. In SANTOS, JE., GALBIATI, C. and MOSCHINI, LE., eds. Gestão e educação ambiental: água, biodiversidade e cultura. São Paulo: RiMa. p. 109123.
SOUZA, HML., CABETTE, HSR. and JUEN, L. 2011. Baetidae (Insecta, Ephemeroptera) em córregos do cerrado matogrossense sob diferentes níveis de preservação ambiental. Iheringia, Série Zoologia, vol. 101, no. 3, p. 181-190. http://dx.doi. org/10.1590/S0073-47212011000200005

SUGA, CM. and TANAKA, MO. 2013. Influence of a forest remnant on macroinvertebrate communities in a degraded tropical stream. Hydrobiologia, vol. 703, no. 1, p. 203-213. http://dx.doi.org/10.1007/ s10750-012-1360-1

THORP, JH., THOMS, MC. and DELONG, MD. 2006. The riverine ecosystem synthesis: biocomplexity in river networks across space and time. River Research and Applications, vol. 22, no. 2, p. 123-147. http:// dx.doi.org/10.1002/rra.901

WAHL, CM., NEILS, A. and HOOPER, D. 2013. Impacts of land use at the catchment scale constrain the habitat benefits of stream riparian buffers. Freshwater Biology, vol. 58, no. 11, p. 2310-2324.

WATSON JAL., ARTHINGTON AH. and CONRICK DL. 1982. Effect of sewage effluent on dragonflies of Bulimba Creek, Brisbane. Australian Journal of Marine and Freshwater Research, vol. 33, no. 3, p. 517-528. http://dx.doi.org/10.1071/MF9820517

WESNER, JS. 2010. Aquatic predation alters a terrestrial prey subsidy. Ecology, vol. 91, no. 5, p. 1435-1444. PMid:20503875. http://dx.doi.org/10.1890/091532.1

WRIGHT, DH. 1983. Species-energy theory: an extension of species-area theory. Oikos, vol. 41, no. 3, p. 496-506. http://dx.doi.org/10.2307/3544109

ZAR, JH. 2010. Biostatistical analysis. Upper Saddle River: Prentice Hall/Pearson. 944 p.

Received: 06 October 2013 Accepted: 18 August 2014 